\title{
Ground Water Quality Assessment of Newly Created Local Governments in Nigeria - A Case of Nkwerre, Local Government, Imo State.
}

\author{
${ }^{1}$ Onunkwo-A. A, ${ }^{2}$ Uzoije A.P, ${ }^{3}$ Onyekuru, S.O, ${ }^{4}$ Agumanu, A. E, and \\ ${ }^{5}$ Chinaemelu, E. S. \\ 1,3,4,5 Department of Goelogy federal university of technology owerri Nigeria. \\ ${ }^{I}$ Department of Environmental technology federal university of technology owerri nigeria .
}

\begin{abstract}
The creation of new Local governments in Nigeria brought about new socio-economic order such as over population, pressure on the available facilities and new land use elements with their generated wastes. There is the need to examine the present status of the underground water resource of these regions for effective development of the newly created local governments. For this reason it becomes necessary to carry out the ground water quality assessment of newly created local governments in Nigeria as a source of data base for development using Nkwerre Local Government Area of Imo State as a case study. The study was carried out by acquiring geologic and topographic maps of the area for easy identification of sample population areas and to identify geological boundaries, Spring out crops, landuse element especially waste dump sites. Agricultural and industrial projects were visited and examined. A total of 6 water samples from bore holes within six communities were collected and analyzed. Analysis was carried out using atomic absorption spectroscopy for major cations. Heavy metal analysis was undertaken using spectrophometer, potassium was determined using flame photometer method, concentration of total iron $\left(\mathrm{Fe}^{2+}\right)$ was determined calorimetrically using spekker absorption meter while total dissolved solids (TDS) was determined using glass fiber filter. Turbidity. Physical parameters like ph and dissolved oxygen were measured insitu in the field with appropriate standard maters. The result of geochemical analysis shows that the water has high turbidity, high iron, slightly acidic, soft portable and suitable for industrial, agricultural and domestic purposes, but requires treatment to reduce iron and turbidity. The water type belongs to a no dominant cation and anion type and can be grouped as $\mathrm{Mg}^{2+}$ $\mathrm{Ca}^{2+}-\mathrm{So}^{2+}-\mathrm{HCO}_{3}$ water. North western segment in infested with ecoli bacteria. The general pollution index of 0.777 shows that the water in the area is ideal for various purposes, however, remediation of iron, turbidity and bacteria presence is proposed.
\end{abstract}

Keywords: evaluation, groundwater, quality Nigeria, contamination, population.

\section{Introduction}

The political creation of new local government in Nigeria brought about population explosion in Villages which were up graded to urban status. The new population explosion brought about the emergence of new land use pressure on the existing land and facilities and likely water pollution due to generated waste. Mans activities such as dumping of refuse and agricultural practices determine the pollution of surface and subsurface ground water (palmer and Holman, 2008) Ground water pollution many also be caused by the disposal of solid or liquid wastes in pits, abandoned boreholes, stream channels and land fills, others are poorly constructed septic tanks and sewage disposal systems (Carrol, 2009) Chemicals such as lead, arsemic and radio active minerals derived from chemical waste disposal sites or factories and mining activities also contribute possible pollutants. The creation of new local government cause migration of people to the areas due to government policy and also calls for new economic order in form of industries, and constructions. That can lead to waste generation. The introduction of contaminant or pollutant into an aquifer system starts with the infiltration of the pollutant through a water medium induced by precipitation (Onunkwo - Akunne and Uzoije 2011). Ground water source (freeze and cherry 1979. Point source can originate from point of diffuse sources point sources of ground water pollution may result from the location of disposal pits, ponds, lagoons, mines or industrial wastes and this goes direct into an unconfined aquifer system. (Raymond, 2001). Diffused ground water pollution source are more complicated and hence difficult to identify and remediate since it is difficult to locate the origin and area of impact of the contamination eg agricultural fertilizer (Raymond, 2001) Water related diseases from subsurface water resource has been reported in the past.

Egbunike (2007) reported high incidence of water related diseases in thickly populated settlement with their source traced to wells. Also palmer and Holman (2008), observed that chemical pollutants such as heavy metals which course cancer and other related diseases was traced to underground water from poorly managed waste source in Dehi City of India. Ground water plays important role in the socioeconomic life of the people. 
The underground water environment is likely to be polluted due to the new Settlement order. In the strength of this, the assessment of the ground water quality of the study area becomes imperative following the unprecedented population explosion occasioned by the movement of the people to the suburbs. This project will also upgrade the ground water data base of the area for various developments associated with the New Local Government.

\section{Description Of The Study Area}

\section{Materials And Method}

Nkwerre local government area is located within Imo Sedimentary basin of South-eastern Nigeria. It is bounded by latitude $7^{\circ} \mathrm{O} 2{ }^{\prime} \mathrm{N}$ to $7^{0} \mathrm{I} 0 \mathrm{~N}$ and Longitude $5^{0} 44 \mathrm{E}$ to $5^{\circ} 47 \mathrm{E}$ and covers and area of about $38 \mathrm{Km}^{2}$ (Iloeje, 1985 ) (Fig 1) with a population figure of about 2,35273 as at 2006 National Population census figure The drainage pattern is dendritic typical of sedimentary rock with uniform resistance and homogeneous geology (Reyment 1965). The area has tropical climate and experiences two air masses equatorial maritime air masses associated with rain bearing south west winds from Atlantic ocean around March to September (iloeje 1985) The other is dry and dusty hamattan an winds from Sahara desert blowing around December to February. The annual total average rainfall is about $230 \mathrm{~mm}$, while temperature ranges, from $29^{\circ} \mathrm{C}$ during dry season to about $33^{\circ} \mathrm{C}$ in rainy season. Relative humidity lies between $65 \%$ and $75 \%$ (Iloeje 1981)

The physiography is dominated by a segment of northern, Southeastern trending Okigwe regional escarpment which stands at elevation of between $61 \mathrm{~m}$ and $122 \mathrm{~m}$ above sea level (Ofomata, 1985). Vegetation in the area is tropical rain forest which is prevalent in the Southern States of Nigeria (Oguntoyimbo, 1987).

Due to great demand of land in the area as a result of the new trend of population pressure, and other human activities the rainforest has been replaced by some economic crops such as oil palm forest, cocoa, rubber, obeche and iroko.

The soil of the area is loamy with scattered pebbles (Ofomata 1985) Thick vegetative cover has prevented soil erosion, however erosion is prominent in the areas where road cuts and forest clearing have opened up the soil to erosion.

The presence of Nanka Sands in some parts is a contributory factor to soil erosion especially where they are exposed unprotected by vegetation. Geologically, Nkwerre local government lies with in Imo drainage basin of South Eastern Nigeria. It is under lain by Ameki Formation and Imo Shales (see fig 2 and table 1).

Ameki Formation which covers most of the surface area is Eocene in age (Reyment, 1965). The geology of Ameki Formation consist of a series of highly fossiliferous grayish-green sandy clay with calcareous white clays. The formation is unconformable and overlain by coarse, mostly continental sandstone of OgwashiAsaba and Benin Formations and underlain by Imo Shale (Kogbe, 1975). According to the author, the formation displays conspicuous facies changes. According to Reyment, (1975), two lithological groups have been recognized in parts, the lower and upper horizons. The lower horizon has fine to coarse sandstones and intercalations of calcareous shale and thin shalay limestones, while the upper zone has coarse cross bedded sandstones, greygreen sand stones and sandy clay.

Table 1 stratigraphic sequence in South Eastern Nigeria (Rayment, 1965)

\begin{tabular}{|c|c|c|}
\hline \multirow[t]{2}{*}{ Neogene } & $\begin{array}{l}\text { Recent } \\
\text { Miocene-plestocene }\end{array}$ & Marine deltaic deposits, alluvium Benin Formation \\
\hline & Oligocene-miocene & Ogwashi-Asaba Formation \\
\hline \multirow[t]{5}{*}{ Paleogene } & Ledan & \multirow{3}{*}{$\begin{array}{l}\text { Not represented } \\
\text { Possibly upper part of Ameki Fm } \\
\text { Ameki formation } \quad \text { Nanka Sands }\end{array}$} \\
\hline & Bartonia & \\
\hline & Lutetian & \\
\hline & Presian & Lower Ameki Formation $\quad$ Sands \\
\hline & Paleocene & Imo Shale \\
\hline \multirow[t]{7}{*}{ Upper Cretaceous } & Danian & Nsukka Formation, \\
\hline & Maestrichtian & Ajali Sanstone \\
\hline & & Mamu Formation \\
\hline & Campanian & Enugu Shale \\
\hline & Coniacian - Santonian & Awgu Shale \\
\hline & Turonian & Ezeaku Shale \\
\hline & Cenomanian & Odukpani Formation \\
\hline Lower Cretaceous & Albian & Asu River Group \\
\hline
\end{tabular}

Fig 1 Topographic Map of Nkwerre Local Government Area. 


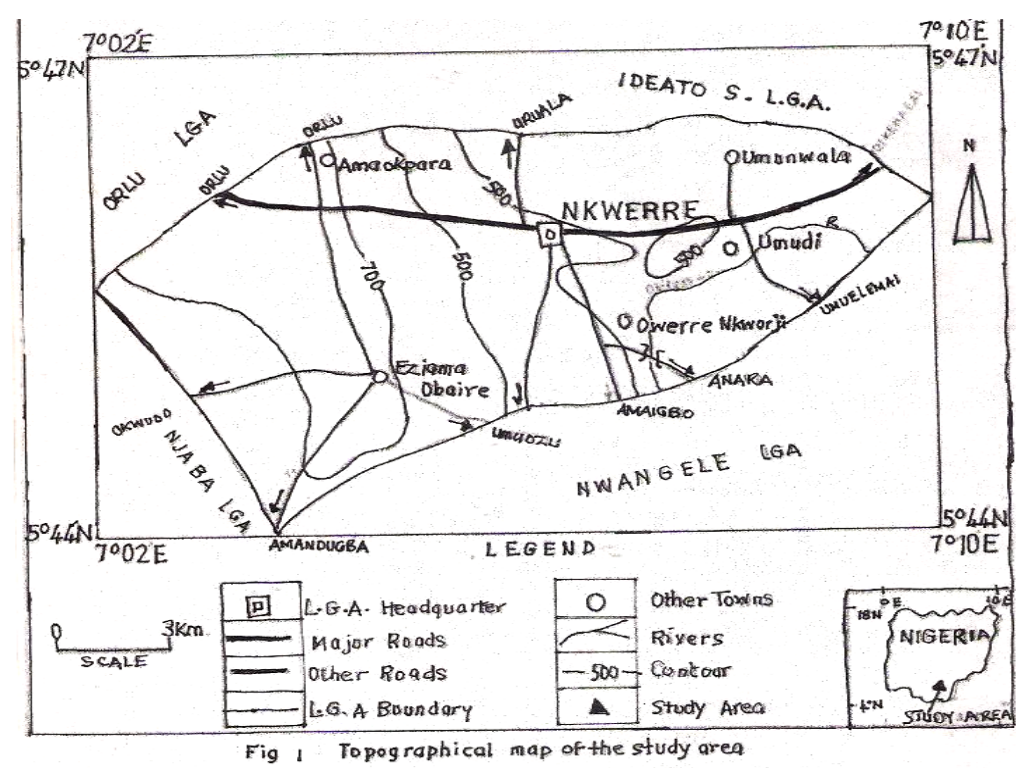

\section{Data Collection}

Data was acquired from field work, laboratory investigations and libraries. Topographic and geologic maps on a scale of 1: 250, 000 was obtained from Nigeria geological survey department, Enugu. Spring out crops, geological boundaries, landuse elements, especially waste dump sites were visited and examined. A total of 6 water samples were collected for organic and in organic analysis in six communities namely: Nkwerre, Owerri Nkworji, Umudi, Amokpara, Umuwalle, and Eziama-Obire. Analysis was carried out using Atomic absorption spectroscopy for $\mathrm{Ca}^{2+} \mathrm{Na}+, \mathrm{Mn}^{2} \mathrm{CL}^{-}, \mathrm{pb}^{2+}$ and $\mathrm{cd}^{2+} \mathrm{Zn}^{2+}$ and $\mathrm{Cu}^{2+}$ were analyzed with the aid of spectrophotometer, while $\mathrm{K}^{+}$was determined using flame photometer method. $\mathrm{Ph}$ was measured insitu with standard ph meter while concentrations of total iron $\left(\mathrm{fe}^{2+}\right)$ were determined calorimetrically using spekker absorption meter. Total dissolved solids (TDS) was determined using glass fiber filter. The concentrations of $\mathrm{Ca}^{2+}, \mathrm{Mg}^{2+}$ and $\mathrm{Na}^{+}$in milliequivalent perlitre were used to obtain sodium absorption ratio (SAR).

Turdibimetric method was used to assess turbidity. Physical parameters like ph and dissolved oxygen were measured insitu in the field with the appropriate standard meters, while anions like $\mathrm{Hco}_{3}, \mathrm{So}^{2-}$ and $\mathrm{Cl}^{-}$ were estimated by titrimetric method. All details of analytical procedures are reported in Sawyer and McCarty (2005). For microbial analysis, Coliform count was carried out as to estimate the presence of bacteria, The method involves most probable number technique (MPN)

In all cases, clean plastic containers were used to contain the water samples. They were rinsed several times with the same water samples to be analysed, then covered with air tight cork and carefully labeled and sent to laboratory for analysis within 24 hours of collection.

Fig 2 Geological map of Nkwerre local government

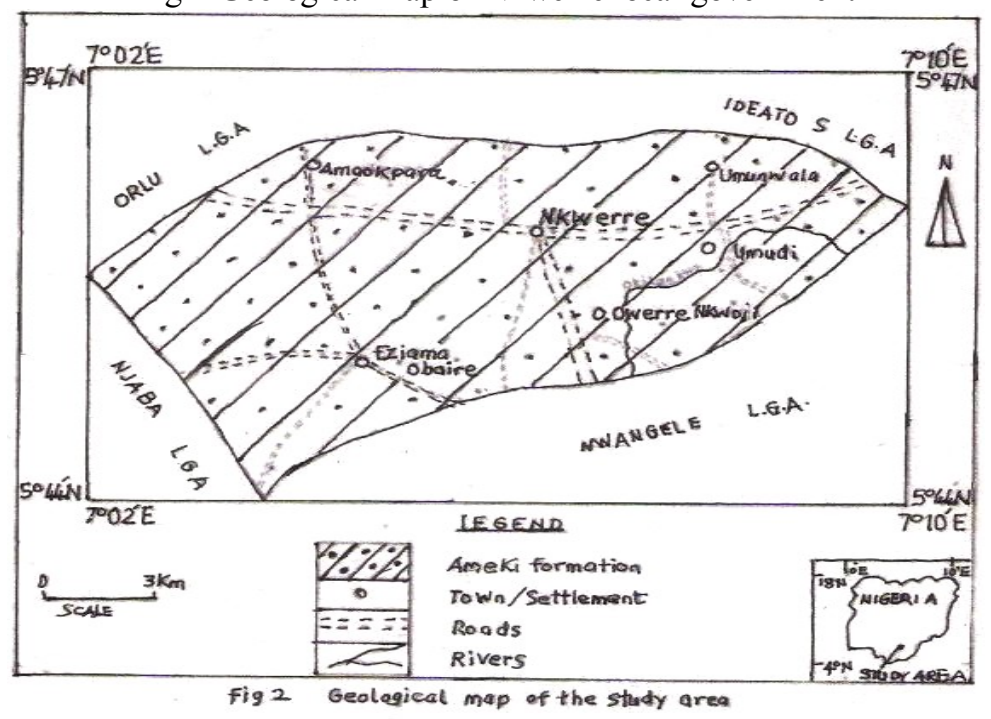




\section{Results And Discussion}

The result of water analysis of the 6 water samples compared with WHO (1984) Standard guide lines for portable water is shown in table 2. It should be observed that there is more dissolved constituents in the underground water of NE and SE of the area. These areas of high dissolved constituents correspond to areas of low elevation and discharge (Freeze and cherry, 1979)

Table 2: Water quality measurement of the area Compound with WHO, 1984

\begin{tabular}{|c|c|c|c|c|c|c|c|c|}
\hline Parameters & Umuwala & $\begin{array}{l}\text { Owerre } \\
\text { Nkworji }\end{array}$ & $\begin{array}{l}\text { Umud } \\
\mathrm{i}\end{array}$ & $\begin{array}{l}\text { Nkwer } \\
\mathrm{e}\end{array}$ & $\begin{array}{l}\text { Amao } \\
\text { kpara }\end{array}$ & $\begin{array}{l}\text { Eziama } \\
\text { Average }\end{array}$ & $\begin{array}{l}\text { Mean } \\
\text { Average }\end{array}$ & $\begin{array}{l}\text { Who } \\
\text { (2004) }\end{array}$ \\
\hline Sodium $(\mathrm{Na}+)$ & 2.26 & 2.84 & 3.51 & 2.29 & 3.47 & 2.49 & 2.81 & 200 \\
\hline Potassium $(\mathrm{K}+)$ & 5.43 & 4.31 & 4.40 & 3.01 & 4.32 & 3.68 & 4.19 & $<50$ \\
\hline $\mathrm{PH}\left(\right.$ at $\left.29^{\circ} \mathrm{C}\right)$ & 7.01 & 3.92 & 6.80 & 6.84 & 6.94 & 7.03 & 6.62 & $6.50-8.50$ \\
\hline Calcium $\mathrm{Ca}^{2+}$ ) & 7.31 & 6.07 & 4.34 & 3.46 & 4.10 & 4.01 & 4.88 & $<50$ \\
\hline Magnesium $\left(\mathrm{Mg}^{2+}\right)$ & 6.14 & 5.10 & 4.08 & 3.99 & 3.53 & 3.46 & 4.35 & $<50$ \\
\hline Total Hardness & 13.45 & 11.17 & 8.42 & 7.45 & 7.63 & 7.47 & 9.27 & $<250$ \\
\hline Total alkalinity & 10.99 & 9.88 & 9.61 & 5.60 & 6.10 & 5.46 & 7.94 & $<50$ \\
\hline Total dissolved Solids (TDS) & 11.41 & 9.64 & 8.34 & 6.19 & 7.81 & 5.89 & 6.21 & $<1000$ \\
\hline Chlorides $\left(\mathrm{C1}^{-}\right)$ & 3.33 & 2.21 & 2.35 & 1.96 & 2.23 & 1.54 & 2.27 & $<250$ \\
\hline Sulphates $\mathrm{CSo}^{2-}$ ) & 5.22 & 4.01 & 2.83 & 2.62 & 2.50 & 1.96 & 3.19 & $<250$ \\
\hline Nitrate $\left(\mathrm{No}_{3}^{-}\right)$ & 1.41 & 1.10 & 1.61 & 1.85 & 1.69 & 0.98 & 1.44 & $<5$ \\
\hline Phosphate $\left(\mathrm{Po}^{2-}\right)$ & 2.30 & 2.69 & 2.61 & 2.85 & 2.34 & 1.31 & 2.35 & $<10$ \\
\hline Iron $\left(\mathrm{Fe}^{2}+\right)$ & 2.46 & 1.25 & 2.11 & 2.47 & 3.26 & 1.96 & 2.25 & $<0.3$ \\
\hline Bicarbonates $\left(\mathrm{HCo}_{3}^{-}\right)$ & 6.20 & 8.90 & 5.16 & 5.98 & 6.12 & 4.33 & 6.12 & $<250$ \\
\hline Total Suspended solids (TSS) & 5.33 & 4.14 & 4.01 & 3.76 & 3.43 & 2.91 & 3.93 & $<50$ \\
\hline Turbidity (NHU) & 12.16 & 11.91 & 11.68 & 9.2 & 9.01 & 6.42 & 10.06 & $<5$ \\
\hline Conductivity (Ms) & 18.31 & 16.46 & 16.01 & 9.34 & 10.16 & 9.1 & 13.23 & $<2000$ \\
\hline
\end{tabular}

The average $\mathrm{PH}$ values for the six water samples is 6.62 which indicates a slightly acidic condition. The average value of total dissolved solids (TDS) is 8.21. The principal constituents of TDS are CL-, So4 ${ }^{2-}$, $\mathrm{Ca}^{2+}, \mathrm{Mg}^{2+}$, and $\mathrm{Hco}_{3}$. Sodium content was used to classify water quality for irrigation purpose because of its reaction with soil to reduce soil permeability (Etu Efeotor, 1981), Thus relation sodium absorption ratio

$\frac{\mathrm{SAR}=\mathrm{Na}+}{\left(\mathrm{Ca}^{2+}+\mathrm{Mg}^{2+}\right)^{1 / 2}} \mathrm{Meq} / \mathrm{L}$

Was employed to determine the suitability of the water for irrigation purpose .According to Etu Efeofor 1981, water class based on SAR is classed as O-10 excellent, 10-18-good $18-26$ fair while $>26$ is poor. Using equation for components derived from table 3, the average SAR is O. 158. This indicates that the water is excellent for agricultural purposes (EtuEfeofor, 1981) form table 2, the average values in $\mathrm{mg} / \mathrm{L} \mathrm{if} \mathrm{Ca}^{2+}, \mathrm{Mg}^{2+}$ $\mathrm{K}+, \mathrm{Na}+, 5 \mathrm{HCO} 3 \mathrm{Fe}+2$ and $+\mathrm{No}_{3}$ among others are 5.653.21, 2.15, 1.05, 9.95, 0.20 and 1.09, these values conform with standard approved by WHO for portable water an indication that the 6 water samples are acceptable based on WHO scale. The average proportion of the percentage concentration of anions- $\mathrm{S} 04^{2}, \mathrm{Cl}-$ and $\mathrm{HC} 03$ also stood at 2.28, 3.50 and 9.95, these also conform with acceptable standard of WHO, (1984) guide line. The result of the conversion of the relevant cation and anion to mill equivalent per litre is shown in table 3

Table 3 Anion and cation concentration in milli equivalent per litre

CATIONS

\begin{tabular}{|c|c|c|c|c|c|c|}
\hline Component & $\begin{array}{l}\text { Conc. } \\
\mathrm{Mg} / \mathrm{L}\end{array}$ & $\begin{array}{l}\text { Atomic } \\
\text { Weight }\end{array}$ & Charge & $\begin{array}{c}\text { Equiv. } \\
\text { Mass (Em) }\end{array}$ & $\begin{array}{c}\text { Conc } \\
\mathrm{Meg} / \mathrm{L}\end{array}$ & $\begin{array}{c}\% \text { of } \\
\text { component }\end{array}$ \\
\hline $\mathrm{Ca}^{2+}$ & 4.88 & 40.08 & 2 & 20.40 & 0.239 & 28.90 \\
\hline $\mathrm{Mg}^{2+}$ & 4.38 & 24.31 & 2 & 12.156 & 0.359 & 43.41 \\
\hline $\mathrm{Na}^{+}$ & 2.81 & 22.98 & 1 & 22.989 & 0.122 & 14.75 \\
\hline $\mathrm{K}^{+}$ & 4.19 & 39.10 & 1 & 39.102 & 0.107 & 12.94 \\
\hline TOTAL & & & & & 0.827 & 100 \\
\hline \multicolumn{7}{|l|}{ ANIONS } \\
\hline $\mathrm{HC} 03$ & 6.12 & 61.02 & 1 & 61.02 & 0.100 & 39.37 \\
\hline N03 & 1.44 & 62.0 & 1 & 62.0 & 0.023 & 9.06 \\
\hline S04 ${ }^{2}$ & 3.19 & 96.06 & 2 & 46.03 & 0.066 & 25.98 \\
\hline $\mathrm{Cl}^{-}$ & 2.27 & 35.45 & 1 & 35.45 & 0.065 & 25.59 \\
\hline TOTAL & & & & & 0.254 & 100 \\
\hline
\end{tabular}


Table 3 was employed to construct pipertrilinear plot (fig3) as to assess the water class and portability. from fig 3, water plots within a no dominant anion and cation type and on the left side of the diamond shape of the pipers plot indicating fresh water

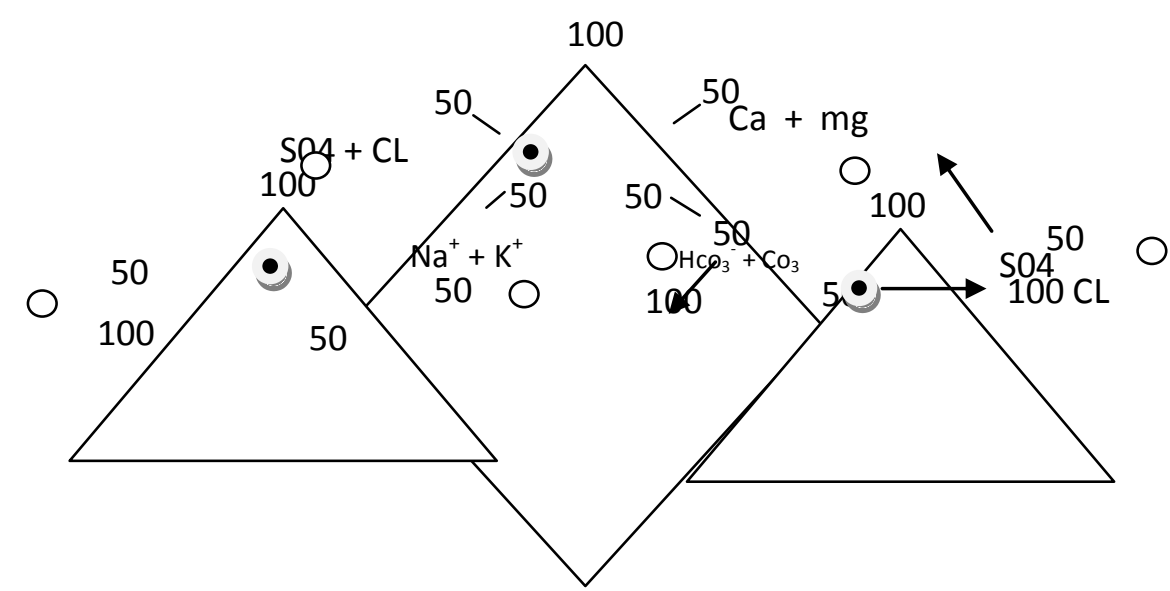

Cation and anion relation in mill equivalent per litre shows that the basic cation constituent are in the following order $\mathrm{Ca}^{2+}>\mathrm{Mg}^{2+}><{ }^{+5}>\mathrm{Na}^{+2}$

For the anions the relation holds as follows $\mathrm{Hco}_{3}>\mathrm{S} 04^{2}>\mathrm{CL}>\mathrm{N03}{ }^{2-}$ This indicated the dominance of $\mathrm{Ca}^{2+}, \mathrm{Mg}^{2+}, \mathrm{Hco}_{3}$ and $\mathrm{So}^{2-}$ water in a mixed from. The result of biochemical analysis is shown in table 4 . It shows the examination of the total coliform count that indicates absence or presence of bacteria in water (Martin 2008)

Table 4 Bacterial analysis of the 6 water samples

\begin{tabular}{|l|l|l|l|l|l|l|l|l|}
\hline Sample & $\begin{array}{l}\text { Total } \\
\text { Piate } \\
\text { count }\end{array}$ & $\begin{array}{l}\text { Dilution } \\
\text { Factor }\end{array}$ & $\begin{array}{l}\text { Organism } \\
\text { Per ml of } \\
\text { sample }\end{array}$ & $\begin{array}{l}\text { Salmo } \\
\text { nella } \\
\text { count }\end{array}$ & $\begin{array}{l}\text { Vibro } \\
\text { Count }\end{array}$ & $\begin{array}{l}\text { Shigella } \\
\text { Count }\end{array}$ & $\begin{array}{l}\text { Clostri } \\
\text { dium } \\
\text { Count }\end{array}$ & $\begin{array}{l}\text { Ecoli } \\
\text { Count }\end{array}$ \\
\hline Umuwala & 20 & $10^{-2}$ & $2.0 \times 10^{3}$ & Nil & Nil & Nil & Nil & Nil \\
\hline $\begin{array}{l}\text { Ezioma } \\
\text { Obire }\end{array}$ & 05 & $10^{-2}$ & $0.5 \times 10^{3}$ & Nil & Nil & Nil & Nil & Nil \\
\hline Umudi & 10 & $10^{-2}$ & $1.0 \times 10^{3}$ & Nil & Nil & Nil & Nil & Nil \\
\hline Nkwerre & 08 & $10^{-2}$ & $0.8 \times 10^{3}$ & Nil & Nil & Nil & Nil & Nil \\
\hline $\begin{array}{l}\text { Owerre- } \\
\text { Nkworji }\end{array}$ & 30 & $10^{-2}$ & $3.0 \times 10^{3}$ & Nil & Nil & Nil & Nil & 6 \\
\hline Amaokpara & 06 & $10^{-2}$ & $0 .-6 \times 10^{3}$ & Nil & Nil & Nil & Nil & Nil \\
\hline
\end{tabular}

The result of the organic analysis of the 6 communities shown in table 4 , indicates that there were no faecal coliform found in most locations except Owerre Nkworji the northwestern section of the study area. On the whole, the high values of turbidity may be due to sediments from erosion and algal growth, Urban run off and flooding as a result of climatic change (Ofodile, 1988). The high level of $\mathrm{Fe}^{2+}$ could be as a result of corrosion of steel pipes (Barnes and Clarke 1980). The possible effects of high iron content in the water are red or yellow staining of laundry and house hold fixtures (Palme et al 1997). The possible health effects are high concentration of iron stored in the pancreas, livers and spleen (Oteze, 1991). High concentration of iron in the body can cause liver and lung problems (Ofodile, 1987) The comparison of chemical analysis of Nkwerre Local Government area underground water with American water works association standard (1991) for industrial water is shown in table 5

Table 5 Ground water analysis result from the study area compared with American water works association (91) AWWA) Standard for industrial water

\begin{tabular}{|l|l|l|}
\hline Parameters & $\begin{array}{l}\text { Average Value of Sample } \\
\text { Analysed Mg/L }\end{array}$ & $\begin{array}{l}\text { AWWA (1991) Accepted } \\
\text { Standard }\end{array}$ \\
\hline TDS & 14.3 & $50-1,500 \mathrm{mg} / \mathrm{L}$ \\
\hline Total Hardness & 8.66 & $0-250 \mathrm{mg} / \mathrm{L}$ \\
\hline Iron $\left(\mathrm{Fe}^{2+}\right)$ & 0.20 & $0.1-1.0 \mathrm{mg} / \mathrm{L}$ \\
\hline PH & 6.90 & $6.5-8.3$ \\
\hline Chloride & 3.50 & $20-250 \mathrm{mg} / \mathrm{L}$ \\
\hline Managanese & - & $0-5 \mathrm{mg} / \mathrm{L}$ \\
\hline
\end{tabular}


With reference to table 5, the groundwater in the area should be treated for iron before they are used for some industries eg laundry. It is possible to assess the pollution level of the local government using the pollution index scale of Horton (1995). The Horton Scale is shown in fig 4

\section{Fig 4 Horton Scale (1995)}

Unity value of (1) indicates a tolerable standard but above this value (1), the water in polluted and below this (1), the water is not polluted. The pollution index is calculated using the formula according to Horton (1995) as shown in equation (2) -pollution Index (Piji):

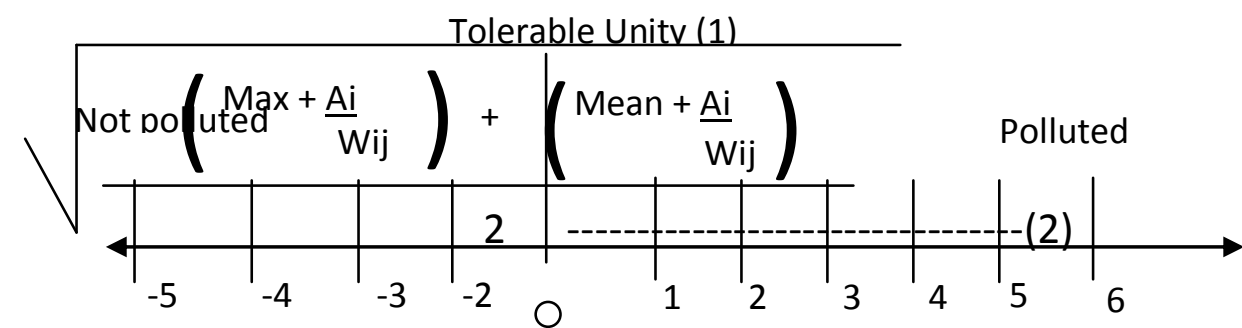

Where $\mathrm{Ai}$ is Average concentrations of the elements in water in $\mathrm{Mg} / \mathrm{L}$ and $\mathrm{Wij}$ is the universal accepted Standard from equation (2). With the total average pollution index (Piji) for the area computed to be 0.77 and compared with the Horton scale, the groundwater resource of the study area is slightly polluted .

This assumption becomes correct since the ground water resource of the tropics is generally characterized by high iron and turbidity due to lateritic cover and erosion. However the presence of coliform in the North West of the study area reduced the water quality to some extent. From the bacteriological analysis of the water sample, the result shows no salmonella, vibriotype, shigella and clostridium contamination but presence of E.coli was found. E.coli indicates contamination by human or animal wastes (Edberg et al 2000) .E.coli in water according to the authors, causes diarrhoea, cramps nausea and headache. Bacteria in water pose special health risk for infants and young children, (WHO, 1996) The ground water resource in slightly acidic. Acid level in water is an indication that there will be more of reduction than oxidation of the metallic contents of the over burden geology leading to high TDS and heavy metal dissolution (Horton, 1995) High PH causes bitter taste, while water using appliances became encrusted (Hem, 1970)

\section{Conclusion And Recommendation}

Apart from high iron and turbidity which are common features of tropical regions the values of the physic-chemical parameters of the water samples meet the standards set by World Health Organization guide line for portable water. The presence of Coliform -E. Coli in the Nw segment of the study area is likely to be a local factor due to faecal contamination or poorly constructed toilet system (Raymond, 1979). The under ground water resource of Nkwerre local government area is fresh, non laxative and good for human consumption, irrigation and industry. Care should be taken as bacterial remediation is necessary especially in the North western segment of the study area. The general assessment of the water quality by Horton (1995) gives the water resources of the area a pass mark.

\section{Reference}

[1]. AWWA(1991) American water works Association Water quality and treatment Mc Graw Hill NewYork, PP654

[2]. Carrol, (2009) Rainwater as a chemical agent of geological process a review of US Gedogical survey water supply paper no3, 15 and 16 PP33038

[3]. Digman, C (2002) Assessment of drinking water in G2 Aipat, India. Journal of Water Resource 12(4), PP 11 -15

[4]. Egbunike M.E (2007) Hydrogeochemical analysis of water samples in Nando and environs of Anambra basin South - Eastern Nigeria, Journal of water resources, India.

[5]. Etuefeotor, (1981) Preliminary hydrochemical investigation of the subsurface waters in parts of Niger Delta mining and geology, 18/1 pp $103-107$

[6]. Freeze, RA and cherry J.A (1979) Ground water Prentice Hall Inc. New Jersy pp 280-285

[7]. Horton (1995) An Index Number rating system for rating water quality pollution control

[8]. Hem, J.D (1970) Study and interpretation of the chemical characteristics of natural water, $2^{\text {nd }}$ edition US Geological survey water supply paper, 1459 ,

[9]. Iloeje, N.P 1981 A New Geography of Nigeria (A new revised edition) Published in great Britain by William Clowes Beccles Ltd, London, pp85-120

[10]. Kogbe, C.A. 1975. Geology of Nigeria. Elizabethan publishing company, Lagos Nigeria. PP $213-220$.

[11]. Martin G. A (1977) Introduction to soil microbiology $2^{\text {nd }}$ ed. Krieger publishing company, New York pp 21

[12]. Onunkwo-A, A and Uzoije, A. P. (2011) Exploratory survey of geochemical aspects of underground water in Ehime Mbano Area SE, Nigeria World Rural Obervations, 3(2) PP $29-37$.

[13]. Offodile, ME, (1987) water resources management and the Nigerian ground water system. Proceedings of delegate conference of the Nigeria academy of science pp23-35 
[14]. Offodile, (2005). The problems of water resources management in Nigeria Nigerian Journal Mining and Geology $20^{\text {th }}$ Anniv. Education (19(1) pp30

[15]. Ofomata, J.C. (1985) Erosion harzards in eastern Nigeria in efficient use of resources pp92 - 100

[16]. Oguntoyinbo, J.S (1987). A geography of Nigerian development. Heinemann Education books (Nig) Ltd. PP $45-70$

[17]. Palmer, R.C. and Holman, I.P (2008) Guide to ground water vulnerability mapping in England Claredon Press London pp 210 - 215

[18]. Reyment, R. A (1965). Aspect of Geology of Nigeria, Ibadan University Press Nigeria $28-32$

[19]. Raymond, C. L. (2001) L and application of wastes, Vol I, John Wiley and Sons publishers, London. Pp15 - 160.

[20]. Sawyer, C. N and McCarthy, Pl (2005) Chemistry for sanitary engineers $2^{\text {nd }}$ ed. Mc.Graw- Hill, New York. Pp 518

[21]. World health Organization (WHO, 1996). Guide Lines for drinking water quality Vol 2. Health criteria and other supporting information (WHO Publ. Geneva pp 335 